Wojciech GIS

Motor Transport Institute (Instytut Transportu Samochodowego)

\title{
ECOLOGICAL AND FUNCTIONAL ASPECTS OF OPERATION OF ELECTRIC VEHICLES WITH FUEL CELL
}

\section{Ekologiczne i funkcjonalne aspekty eksploatacji pojazdów samochodowych z ogniwami paliwowymi}

\begin{abstract}
Hydrogen can have great importance in seven areas of necessary changes in the transformation of the power system, including transport (especially motor transport), industrial processes, thermal and energy production in the construction industry and production processes. Hydrogen fuel cell electric vehicles (FCEVs) do not cause local air pollution because they have zero "tailpipe" emissions. Essential are ecological and functional aspects of operating vehicles equipped with fuel cells. However, noteworthy is also the development of the refilling infrastructure. The functionality of FCEVs to a considerable degree depends on the functionality of fuel cells.
\end{abstract}

Keywords: ecology, vehicles (FCEV), infrastructure

Streszczenie: Wodór może mieć ogromne znaczenie $w$ siedmiu obszarach niezbędnych zmian transformacji systemu elektroenergetycznego, $w$ tym $w$ transporcie (zwłaszcza $w$ transporcie samochodowym), procesach przemystowych, produkcji ciepla i energii w budownictwie oraz procesach produkcyjnych. Elektryczne pojazdy wodorowe z ogniwami paliwowymi (FCEV) nie powoduja lokalnie zanieczyszczenia powietrza, ponieważ maja zerowa emisje $z$ „,wydechu”. Istotnymi sa ekologiczne i funkcjonalne aspekty eksploatacji pojazdów wyposażonych $w$ ogniwa paliwowe. Jednak istotnym jest także rozwój infrastruktury ich tankowania. Funkcjonalność pojazdów (FCEV) $w$ istotnym stopniu zależy od funkcjonalności ogniw paliwowych.

Słowa kluczowe: ekologia, pojazdy (FCEV), infrastruktura 


\section{Introduction}

Industrial methods of producing hydrogen are as follows: steam methane reforming (approx. 48\%), partial oxygenizing of refinery remnants (approx. 30\%), carbon gasification (approx. 18\%), electrolysis of water (approx. 4\%). Roughly 50\% of the produced hydrogen is used for refinery-related needs and approx. $40 \%$ for the production of ammonia. In 2017 the overall global production of hydrogen came to approx. 70 million tons, of which in China - approx. 14 million tons, the US - approx. 13 million tons, India - approx. 5 million tons, in Canada, Japan and Russia - c.a. 4 million tons each, in France and Germany approx. 3 million tons each, in Australia - c.a. 2 million tons, in Saudi Arabia, South Korea and Poland roughly 1 million tons each $[3,4,10]$.

By the end of 2018 about 360000 fuel cells were sold worldwide, with a total output of approx. $2500 \mathrm{MW}$, including: approx. 43000 were fitted in means of transport, mainly in materials handling vehicles (approx. 22000 - of which c.a. 21600 in the US), nowadays 25000 units, approx. 20500 in passenger cars, approx. 500 in buses [3,4,10].

In 2018 the global sales came to approx. 75000 fuel cells with an overall output of approx. $800 \mathrm{MW}$, i.e. 4000 units and $145 \mathrm{MW}$ more than in 2017. In 2018 approx. 11500 units with a total output of c.a. $560 \mathrm{MW}$ were fitted in means of transport. In the transport sector, the commonly used fuel cell is the proton exchange membrane fuel cell (PEMFC) $[3,4,8]$.

\section{Present state and prospects of development of FCEV, FCEB and trucks}

Presently, there are approx. 15 thousand FCEV, with c.a. 400 heavy vehicles and roughly 500 buses, mainly city buses in the world [10]. At the end of 2017, there were 7186 FCEVs used in the world (fig. 1). As of 4 April 2018, there were 4411 FCEVs registered in California alone.

Vehicles equipped with fuel cells are available. Three models of FCEV are already offered commercially in Japan, South Korea, California, and Germany (Toyota Mirai, Honda Clarity, Hyundai ix35/Tucson), and one model is available as a retrofit (Renault Kangoo, retrofitted by Symbio FCell). Ten additional models are slated for release by 2020. FCEV have driven more than 20 million $\mathrm{km}$ under real world conditions and satisfy all safety certifications and regulations [7].

But cars are still only really produced by Toyota and Hyundai [4tech]. In September 2019, the $10,000^{\text {th }}$ Mirai left Toyota's production line and Toyota also increased the production capacity of the said vehicle toto 30,000 vehicles annually. Honda comes in third but has shipped few Clarity FCEV. In Japan, there were approx. 2300 FCEVs in 2017 (at present approx. 3500). The Hyundai NEXO has been well received [3,4]. 


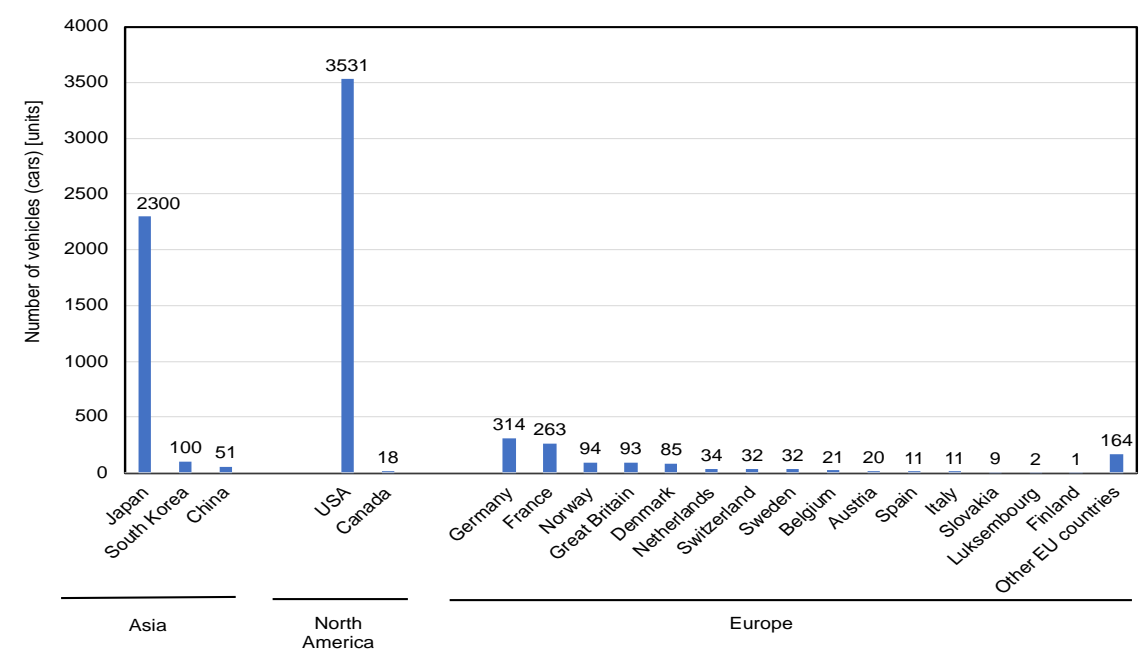

Fig. 1. Number of FCEVs at the end 2017

BMW teased with its iHydrogen NEXT concept car but doesn't expect commercialisation until 2025. And Audi will increase its investment in fuel cell technology and plans on a limited-run pilot production FCEV by $2021[3,4]$.

In China, SAIC has sold mainly Maxus vans. Development of its Roewe car is ongoing, as are cars programmes at several other manufacturers $[3,4]$.

Luxury car company Grove launched in March, after what it says was a three-year process of hydrogen vehicle development. It claims excellent performance for its cars, including 1,000 km range. Two hundred were supposed to be on the road by the end of 2019 in a ride-sharing scheme, and mass production capability of 5,000 per year is forecast in 2020. California is the global leader in car deployment as more than 7,500 were on public roads as of November 2019 [3,4].

FCEV passenger cars could represent almost 3\% of new vehicles sales in 2030, ramping up to about $35 \%$, for total sales of 4 million vehicles in 2030 . In the markets leading global FCEV adoption, Germany, Japan, California, and South Korea, almost every $12^{\text {th }}$ car sold in 2030 could be powered by hydrogen [7].

Small vans and light commercial FCEVs are used today. Adoption could increase to almost $6 \%$ of sales by 2030 and almost $50 \%$ by 2050 , as cities put more stringent regulations in place to reduce local emissions from delivery vehicles and other commercial fleets [7].

At the end of 2017, there were 254 fuel cell electric buses (FCEB) used and roughly 200 prototypic (demo) buses. There are about 500 FCEBs used in the world [16]. These are buses of: ADL, Daimler, Beiqi Foton, Solaris, Van Hool, VDL, and Wrightbus are on the road in the US, Europe, Japan, and China today [7].

The European JIVE projects are are an important driving force, targeting 290 buses across Europe, of which Groningen in the Netherlands ordered 20 out and planned 50 Van Hool buses in July 2019, and London ordered 20 Wright double-decker buses. After JIVE 
project comes the project named H2Bus Europe, formally launched in June 2019. A consortium including Ballard Power, WrightBus and Nel is seeking to deploy 1,000 FCEBs -assisted by $€ 40 \mathrm{~m}$ (US\$47.4m) from the European Union's Connecting Europe Facility [4].

At the end of 2018 the USA was reported to have 35 buses running, with another 39 planned. More buses should be running in China than in Europe, and one source claims that 126 buses delivered by the end of the 3rd quarter 2019, but it remains unclear how many are in active service [4].

Nevertheless, a growing number of Chinese companies are offering or developing FCEBs. In 2019 Geely company launched its F12 FCEB; Beiqi Foton company exhibited its FCEB offered in November 2019, and is aiming to deploy 1000 units by the end of 2022; Golden Dragon company announced that it will deliver 100 FCEBs, comprising 8.5 and $12 \mathrm{~m}$ vehicles, for Zhejiung Province by the end 2020 [4].

Thirty-seven buses were to be funded in Korea in 2019 adding to the seven from 2018 of the 2,000 buses planned for 2022. Buses come from Hyundai, which is also slated to replace 802 buses operated by the police force with FCEBs between 2021 and 2028, not least to reduce the emissions which often come from the buses idling in cities [4].

Japan planned to have 100 buses in service in 2020, for the Tokyo Olympics, and 1,200 running by 2030 . At least 18 are already in service in and around Tokyo. All are Toyota's $10.5 \mathrm{~m}$ Sora, updated for 2019 [4].

There are roughly 400 trucks and c.a. 100 vans equipped with fuel cells that are used in the world [10]. The situation is changing rapidly, as proven by the Hyundai sales to Switzerland in 2019-2024 of 1600, 18-ton hydrogen trucks. Nikola Motor Company has secured substantial funding and a high volume of pre-orders for its semi-truck, including a resently unveiled European model, the Nicola Tre [10]. For example, China leads the global deployment of fuel cell electric trucks and accounts for the majority of demonstration projects. Outside China, FedEx and UPS are trialling fuel cell range extender Class 6 delivery vehicles in the United States. In the h2Share project is planned to test a 27-tonne heavy duty trucks in Europe $[1,3,10]$.

Globally 10 to 15 million cars and 500000 trucks are expected to be hydrogenpowered in 2030. Up to 400 million passenger vehicles ( 25\%), 5 million truck $(\sim 30 \%)$, and more than 15 million buses ( $25 \%)$, most likely is to be equipped with fuel cells in 2050 [7].

\section{Ecological aspects of using FCEV}

In general, the present demand for hydrogen in its pure form is around 70 million tonnes per year $\left(\mathrm{MtH}_{2} / \mathrm{yr}\right)$. This hydrogen is almost entirely supplied from fossil fuels, with $6 \%$ of global natural gas and $2 \%$ coal going to hydrogen production (a furtner $45 \mathrm{MtH}_{2} / \mathrm{yr}$ are used in industries such as steel and methanol production without prior separation of the other gases). As a consequence, production of hydrogen is responsible for carbon dioxide 
$\left(\mathrm{CO}_{2}\right)$ emissions of around 830 million tonnes of carbon dioxide per year $\left(\mathrm{MtCO}_{2} / \mathrm{yr}\right)$, equivalent to the $\mathrm{CO}_{2}$ emissions of Indonesia and the United Kingdom combined [10].

Hydrogen is light, storable, reactive, has high energy content per unit mass, and can be readily produced at industrial scale. Today's growing interest in widespread use of hydrogen for clean energy systems rests largely on two additional attributes: it can be made from a diverse range of low-carbon energy sources. Its potential supply includes production from renewable electricity, biomass and nuclear [10].

The production of hydrogen currently generates approx. $10 \mathrm{tCO}_{2} / \mathrm{tH}_{2}$ with the use of natural gas, c.a. $12 \mathrm{tCO}_{2} / \mathrm{tH}_{2}$ with the use of refinery remnants and approx. $19 \mathrm{tCO}_{2} / \mathrm{tH}_{2}$ using coal, and only roughly $1 \mathrm{tCO}_{2} / \mathrm{tH}_{2}$ using water electrolysis and renewable energy sources [10]. That determines the functioning of fuel cell vehicles in the life cycle in terms of $\mathrm{CO}_{2 \text { eqv }}$ emissions in comparison with conventional vehicles and EVs. Noteworthy are also the costs of using vehicles (passenger cars) equipped with fuel cells, the costs of fuel cells or HRS and the refuelling infrastructure [9].

Using hydrogen instead of carbon-containing fuels in energy end-uses could also reduce local air pollution, improving environmental and health outcomes. When used in vehicles, hydrogen does not produce particulates and nitrogen oxides [10].

FCEVs can achieve very low $\mathrm{CO}_{2}$ emissions if the whole lifecycle is considered (fig. 2). Such emission is comparable with the emission of an electric vehicle in the lifecycle (C-segment - green electricity; green/clean $\mathrm{H}_{2}$ ).

$\mathrm{CO}_{2}$ emissions, 2015, $\mathrm{g} / \mathrm{km}$

\begin{tabular}{|c|c|c|c|c|c|}
\hline Geen electricity & $\sim 10$ & $-25-35$ & $65-75$ & & BEV \\
\hline Spain & -35 & $\sim 30$ & $\sim 25-70$ & $90-135$ & \\
\hline Germany & $\sim 55$ & & -30 & $110-155$ & \\
\hline US & $\sim 60$ & & -30 & $-25-70 \quad 115-160$ & \\
\hline China & & & & $\sim 25-70 \quad 135-180$ & \\
\hline
\end{tabular}

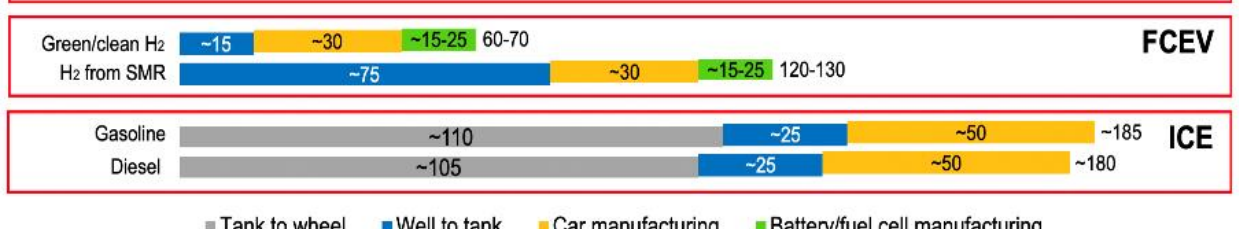

$=$ Tank to wheel $\quad$ Well to tank $\quad$ Car manufacturing $\quad$ Battery/fuel cell manufacturing

Assumption: compact car (C-segment) as reference vehicle (4.1 1/100 km diesel; 4.8 1/100 km gasoline; 35.6 kWh battery), 120,000 km lifetime average grid emissions in China, Germany, Spain in 2015; EV manufacturing (excl. fuel cell and battery) $40 \%$ less energy-intensive than ICE manufacturing; $10 \mathrm{~kg} \mathrm{CO} 2 / \mathrm{kg} \mathrm{H} 2$ from SMR; $0.76 \mathrm{~kg} \mathrm{H} 2 / 100 \mathrm{~km} ; 13 \mathrm{kWh} / 100 \mathrm{~km}$

Fig. 2. $\mathrm{CO}_{2}$ emissions if the whole lifecycle is considered (FCEV, BEV, ICE) [7] 
Table 1 presents the values of lifecycle emissions for various FCEVs [12].

Table 1

Emission of greenhouse gases in the use of various fuels

\begin{tabular}{||l|l|l||}
\hline \multicolumn{1}{|c|}{ Type and origin of a fuel } & \multicolumn{1}{|c||}{$\begin{array}{c}\text { Direct emission by vehicles } \\
{[\mathrm{kg} \mathrm{CO} 2 \mathrm{eqv} / 100 \mathrm{~km}]}\end{array}$} & $\begin{array}{c}\text { Total gross emission } \\
\text { including fuel production } \\
{[\mathrm{kg} \text { CO2eqv/100 km] }}\end{array}$ \\
\hline Vehicle using biogas & $<8,4$ & 8,4 \\
\hline $\begin{array}{l}\text { Vehicle with a self-ignition } \\
\text { engine, effective in terms of } \\
\text { fuel consumption }\end{array}$ & 9,8 & $>9,8$ \\
\hline $\begin{array}{l}\text { Vehicle fueled with E85 } \\
\text { Vehicle using fuel cell, wind } \\
\text { power }\end{array}$ & 0,0 & $\begin{array}{l}\text { Depends on the origin of } \\
\text { ethanol }\end{array}$ \\
\hline 1average for vehicles of several producers; * including 0,7 from wind turbine production \\
\hline
\end{tabular}

\section{Functional aspects of using FCEV}

For the development of hydrogenization of the motor transport it is essential that the HRS infrastructure is expanded. At the end of 2017 there were 332 hydrogen refuelling stations worldwide, whereas as of 4 April 2018 in California alone there were 64 HRS. Presently, there are 378 hydrogen refuelling stations used in the world (fig. 3).

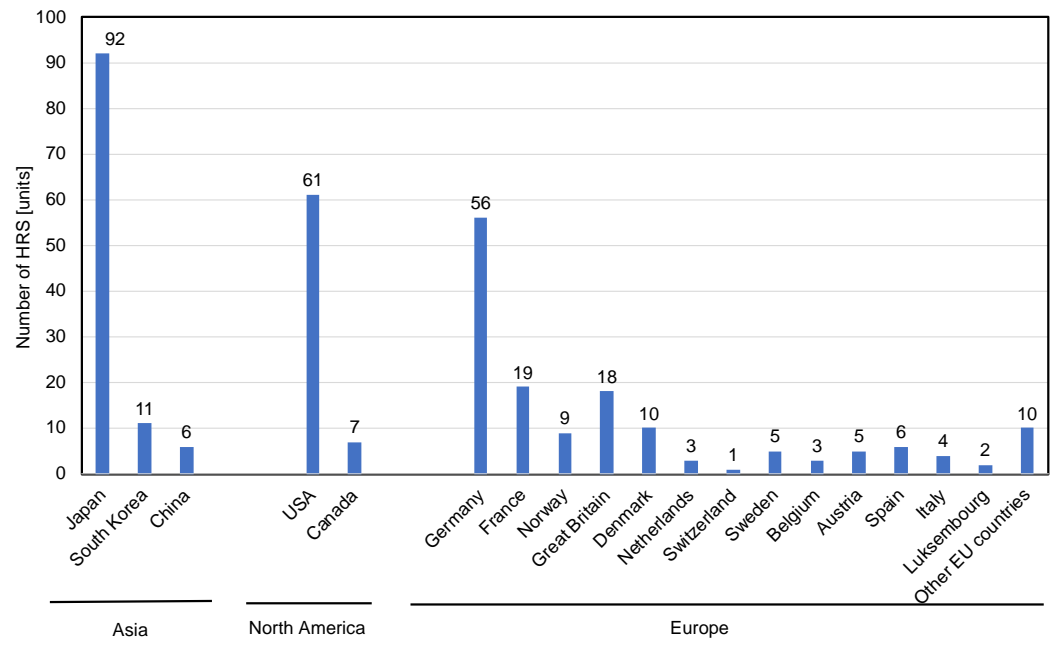

Fig. 3. Number of HRS at the end of 2017 
The development of the HRS infrastructure differs from the assumptions, an example of which can be the number of hydrogen refilling stations in California - 44 (compared with the planned $100 \mathrm{HRS}$ in 2020), in Japan - 130 HRS (vs the planned $160 \mathrm{HRS}$ in 2020), and 78 hydrogen refilling stations in Germany at the end of December 2019 compared with the targeted 100 HRS by mid-2020 (and planned 400 hydrogen refilling stations in 2023-2025). Noticeable is the disproportion of the number of FCEVs compared with the number of refilling stations - for example in Germany - approx. $60 \mathrm{HRS}$ and roughly 10 FCEVs served by one station. For a fully developed infrastructure, 2500-3500 FCEV per station are expected [10].

The cost of constructing a hydrogen refuelling station was equal to c.a. USD $1.5-2.5$ million (a station allowing for the distribution of $200 \mathrm{~kg}$ of $\mathrm{H}_{2}$ per day), we in the early implementation stage. Nowadays about USD 1.25 - 1,5 million per large station, smaller stations involve a cost of approx. USD 1.2 million (Germany) [7, 9]. In Japan the costs are three to five times higher due to regulatory requirements and geographical and geological conditions [7].

In the longer term over $400 \mathrm{HRS}$ would be needed to service a fleet of 1 million hydrogen FCEVs if the ratio of refuelling stations to cars were similar to that for today's oil-powered car fleet. This compares to almost 1 million private charging stations and at least 10000 fast-charging public stations that would be needed for a fleet of 1 million BEVs $[1,5,10,11]$.

Most fuelling stations serving non-captive fleets in the early stages of FCEV deployment will be small $\left(<200 \mathrm{kgH}_{2} /\right.$ day), and the total investment needed to build these 400 stations is likely to be on the order of USD $0.5-0.6$ billion. For a mature market with larger stations (>1000 kg/d) an investment of USD 35-45 billion would be required to serve just $5 \%$ of the global car fleet (around 60 million vehicles). Necessary is a collaboration with industrial stakeholders on roadmaps for building HRS in the initial phases [10].

Figure 4 presents the expected number of HRS in 2030. More than 5,000 hydrogen refuelling stations have been announced [7]. 
Latest announced investments in hydrogen refueling stations (selected countries)

EUROPE
H2Mobility Germany - up to 400 HRS by 2023
H2Mobility UK - up to $1150 \mathrm{HRS}$ by 2030
Scandinavia - up to $150 \mathrm{HRS}$ by 2020
Other Europe - $820 \mathrm{HRS}$ by 2030
US
Northeasten US - 250 HRS by 2027
California - $100 \mathrm{HRS}$ by 2020
ASIA
China - 1000 HRS by $2030 ;>1$ milion FCEV's
South Korea - 310 HRS by 2022
Japan - 900 HRS by 2030

Current global announcements ${ }^{1}$

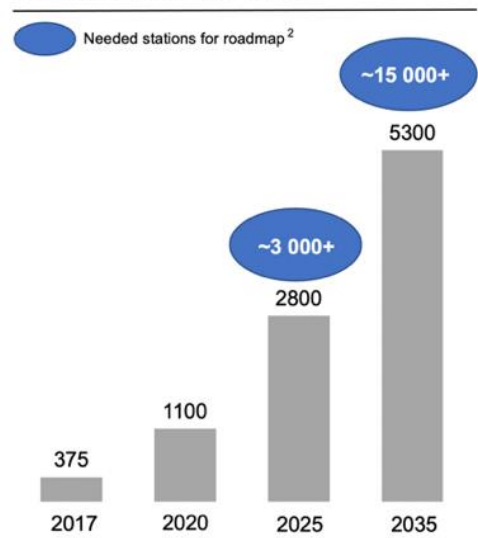

1 Announcements for shaded countries/regions: California, Northeastern US, Germany, Denmark, France, Netherlands, Norvey, Spain, Sweden, UK, Dubai, China, Japan, South Korea

${ }^{2}$ Equivalent number of large stations (1000 $\mathrm{kg}$ daily capacity)

Fig. 4. The expected number of HRS in 2030 [7]

FCEVs characterise with a range of approx. $600 \mathrm{~km}$. There are prototype vehicles with a range of $800 \mathrm{~km}$, and FCEVs with a range up to $1000 \mathrm{~km}$ are expected in 2030 (fig. 5).

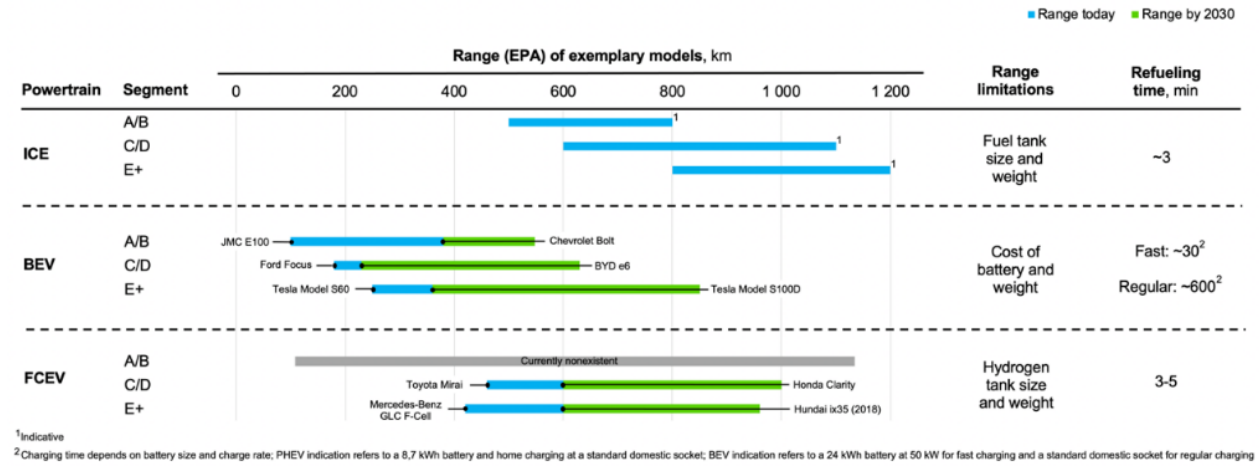

Fig. 5. FCEV range and refueling times [7]

Table 2 shows the prices of the FCEV vehicle and the prices of some of its components. The cost of FC in the cost of the vehicle is significant. 
Prices of FCEV and some of its components [9]

\begin{tabular}{||c|c|c|c|c||}
\hline & Today & $\mathbf{2 0 3 0}$ & $\mathbf{2 0 5 0}$ & Unit \\
\hline FCEV costs & 60000 & 33600 & 33400 & USD \\
\hline Glider & 23100 & 24100 & 25600 & USD \\
\hline Fuel cell system & 30200 & 4300 & 3200 & USD \\
\hline $\mathrm{H}_{2}$ tank & 4300 & 3100 & 2800 & USD \\
\hline Battery & 600 & 460 & 260 & USD \\
\hline $\begin{array}{c}\text { Electric motor and } \\
\text { power control }\end{array}$ & 1800 & 1600 & 1400 & USD \\
\hline
\end{tabular}

As regards the costs of purchasing a fuel-cell bus (FCEB), the refilling time and range, those parameters are as follows: costs of purchase - approx. EUR 550 thousand - 650 thousand (European project Jive I and Jive II - cost of purchasing 300 FCEBs to 2023 for 22 cities in Europe), which means that the price dropped by roughly 1/3 compared with the current price, with the unit production (approx. EUR 715 thousand - 845 thousand); according to FCH-JU the price of FCEB is to amount approx. EUR 500 thousand in 2023; the price of EUR 350 thousand - 400 thousand is possible if more than 100 buses are ordered annually; bus refilling - 10-15 minutes; range of FCEB - approx. 300-450 km.

A number of countries adopted National Implementation Plan (NIP) for hydrogenization of transport. In Poland only the Motor Transport Institute developed "Circumstances for the national plan for hydrogenization of road transport".

\section{Circumstances for the national plan for hydrogenization of road transport (Poland)}

The territorial accessibility for hydrogen vehicles is determined by the availability of hydrogen refuelling infrastructure, in the first place along with the TEN-T network [6].

As a result of the verification, in Polish conditions (during realization European project HIT-2-Corridors), of the original method developed for determining the initial location of the hydrogen refuelling station in Poland, in the pre-commercial phase (2020-2030), the said location has been indicated along with the order of investment, taking into account above all the freedom to move around Poland of cars powered by hydrogen visiting Poland and transiting our country between other EU countries [6].

Despite the strategic importance of developing hydrogen filling stations infrastructure, in the available materials, including various national programs for hydrogen propulsion technology developments, the explicitly formulated programming methodology for the development of these stations, has not been encountered.

The methodology developed is of a multi-stage character. Individual steps leading to the designation of the location of hydrogen refuelling stations in Poland (as the 
methodology alone seems to be universal) are as follows: stage I-method allowing to identify regions in which the hydrogen refuelling stations should be located in the first place, stage II-method allowing to identify urban centres, in which should be located the said stations, stage III-method for determining the area of the station location [6].

The table 3 shows method allowing to identify regions (stage I), urban centres (stage II), area of the station location (stage III).

Table 3

Method allowing to identify regions (stage I), urban centres (stage II), area of the station location (stage III) [6]

\begin{tabular}{||l|l|l||}
\hline \multicolumn{1}{|c|}{ Stage I } & \multicolumn{1}{|c|}{ Stage II } & \multicolumn{1}{c|}{ Stage III } \\
\hline Average GDP per capita & $\begin{array}{l}\text { Average distance of the cities, } \\
\text { over 250 thousand } \\
\text { inhabitants, from the place of } \\
\text { hydrogen manufacture } \\
\text { (acquisition) }\end{array}$ & $\begin{array}{l}\text { Results of locating the } \\
\text { stations in question obtained } \\
\text { in stage I and II, and relying } \\
\text { on the results of the } \\
\text { measurement of average } \\
\text { traffic volume of passenger } \\
\text { cars on the roads leading to } \\
\text { these cities or on selected road } \\
\text { junctions located near these } \\
\text { cities }\end{array}$ \\
\hline $\begin{array}{l}\text { Average population density } \\
\text { (inhab. } / \mathrm{km}^{2} \text { ) }\end{array}$ & $\begin{array}{l}\text { Average distance of the cities } \\
\text { over 250 thousand inhabitants } \\
\text { from the nearest hydrogen } \\
\text { refuelling station located } \\
\text { outside Poland }\end{array}$ & $\begin{array}{l}\text { Traffic flow intensity of } \\
\text { passenger cars was included } \\
\text { on the roads leading to the } \\
\text { following cities: Warsaw, } \\
\text { Poznan, Krakow, Wroclaw, } \\
\text { Katowice (Upper Silesia } \\
\text { conurbation), Tri-City, } \\
\text { Szczecin, Lódź, Białystok }\end{array}$ \\
\hline $\begin{array}{l}\text { The number of people living } \\
\text { in the largest cities in the } \\
\text { region, out of the cities with } \\
\text { 250 thousand inhabitants }\end{array}$ & Number of taxies in the city \\
\cline { 1 - 2 } $\begin{array}{l}\text { Average traffic volume of } \\
\text { passenger cars on the national } \\
\text { roads of international } \\
\text { significance running through } \\
\text { the region (passenger cars/24 } \\
\text { hours) }\end{array}$ & $\begin{array}{l}\text { Number of municipal } \\
\text { transport buses }\end{array}$ & \multicolumn{2}{|l||}{} \\
\hline
\end{tabular}

Additionally, while pre-indicating subsequent hydrogen station locations consideration was given to the following: average passenger car traffic intensity and average traffic volume projected for 2020, development of hydrogen filling stations network in the country, development of hydrogen refuelling stations in areas with potentially high demand for hydrogen fuel also by fleets of buses and taxis.

The order of investment: while taking into account the initial HRS locations (Stages IIII), in the first place included were: existing hydrogen refuelling capabilities in the neighbouring countries, the assumed future hydrogen refuelling stations locations in the Baltic Sea countries, new stations at the distances up to approx. 300 kilometres away from the existing stations or sequentially from the newly - opened stations. 
With the above criteria, the order the construction of hydrogen refuelling stations in Poland: 1 - Poznan 2 - Warsaw, 3 - Bialystok, 4 - Szczecin, 5 - the Lodz region, 6 - the Tri-City region, 7 - Wroclaw, 8 - the Katowice region, 9 - Kraków.

Figure 6 shows: a) the proposed location of base hydrogen refuelling stations in Poland until 2030, along with the order of their construction in the national TEN-T corridors b) the movement area of cars using fuel cells based on 9 base hydrogen refuelling stations situated in the national TEN-T road network by 2030 .

a)

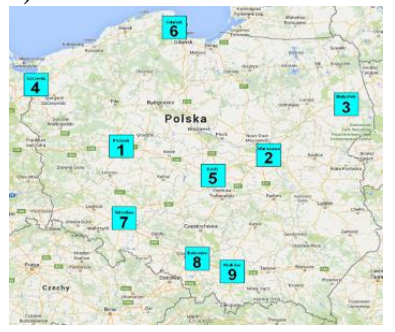

b)

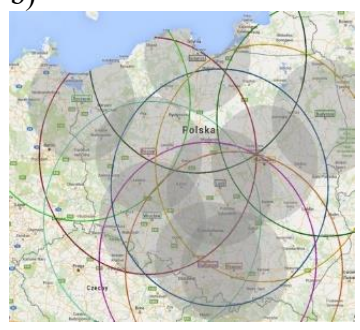

Fig. 6. a) The proposed location of base hydrogen refuelling stations in Poland until 2030, along with the order of their construction in the national TEN-T corridors b) The movement area of cars using fuel cells based on 9 base hydrogen refuelling stations situated in the national TEN-T r oad network by 2030: 1) when driving in one direction (large circles - to approx. $600 \mathrm{~km}$ ), 2) when driving back and forth (small circles - to approx. $300 \mathrm{~km}$ ) [6]

\section{Conclusions}

Decarbonization of motor transport is presently implemented in terms of applying hydrogen by using - within the possible scope - passenger cars equipped with fuel cells and urban buses also equipped with such cells. As regards trucks, it is in the initial phases of development, although it is the most important.

The development of the refilling infrastructure for fuel-cell vehicles determines the development of hydrogenization of road transport. This article presents some ecological and functional aspects relating to their use.

\section{References}

1. ACEA report: Vehicles in use Europe 2018.

2. AFC TCP: Survey on the Number of Fuell Cell Electric Vehicles, Hydrogen Refuelling Stations and Targets, provided to IEA by AFC TCP, 2018.

3. E4tech: The Fuel Cell Industry Review 2018.

4. E4tech: The Fuel Cell Industry Review 2019. 
5. FuelsEurope: Statistical Report 2018.

6. Gis W., Menes E., Waśkiewicz J., et al.: Circumstances of the national plan for hydrogenization of road transport in Poland. ITS, Warsaw 2015.

7. Hydrogen scaling up: A sustainable pathway for the global energy transition. Hydrogen Council. November 2017.

8. Hydrogen Roadmap Europe: A sustainable pathway for the European energy transition. FCH, 2019.

9. IEA: Technology Roadmap. Hydrogen and Fuel Cells. OECD/IEA, 2015.

10. IEA: The Future of Hydrogen. Seizing today's opportunities, June 2019.

11. Robinius M., et al.: Comparative Analysis of Infrastructures: Hydrogen Fueling and Electric Charging of Vehicles, 2018.

12. Wallmark C., Schaap G.: Hydrogen infrastructure for transport. Facts and conceptual plan for Sweden, Sweco 2014. 